\title{
Biochemical, Structural, and Functional Abnormalities of Polymorphonuclear Leukocytes in the Neonate
}

\author{
HARRY R. HILL \\ Division of Clinical Immunology and Allergy, Departments of Pediatrics and Pathology, University of Utah \\ School of Medicine, Salt Lake City, Utah 84132
}

\begin{abstract}
The human neonate is uniquely susceptible to serious and overwhelming bacterial and fungal infections. While deficiencies of antibody, complement, and $T$ lymphocytes certainly contribute to this susceptibility, abnormal polymorphonuclear leukocyte function appears to be a major host defense abnormality in the neonate. Functional defects in neonatal polymorphonuclear leukocyte adherence, aggregation, movement, phagocytosis, and intracellular killing have been described in the term or preterm infant. Only recently, however, have the techniques become available to examine the biochemical and structural mechanisms underlying abnormal polymorphonuclear leukocyte function in the neonate. It now appears that there may be developmental defects in signal transduction, cell surface receptor upregulation and mobility, cytoskeletal rigidity, microfilament contraction, oxygen metabolism, and intracellular antioxidant mechanisms. Defining the biochemical and physiologic abnormalities in these cells may lead to therapeutic regimens for pharmacologically correcting these developmental defects in cell function. (Pediatr Res 22: 375-382, 1987)
\end{abstract}

\section{Abbreviations}

F actin, filamentous actin

PMN, polymorphonuclear leukocyte

Con $\mathbf{A}$, concanavalin $\mathbf{A}$

kD, kilodaltons

LFA-1, leukocyte function associated-antigen

FMLP, formyl-methionyl-leucyl-phenylalanine

NBD, nitrobenzoxadiazole

PAF, platelet activating factor

TPMP+, triphenylmethyl phosphonium

$\mathrm{DiOC}_{5}(3)$, dipentaloxacarbocyanine

cAMP, cyclic adenosine monophosphate

ATP, adenosine triphosphate

NADPH, nicotinamide adenine dinucleotide phosphate

NADP ${ }^{+}$, reduced nicotinamide adenine dinucleotide phosphate

LTB $_{4}$, leukotriene $B_{4}$

CL, chemiluminescence

PHA, phytohemagglutinin

PMA, phorbol myristate acetate

2GSH, reduced glutathione

GSSG, glutathione

Received May 15, 1987; accepted May 15, 1987.

Correspondence and reprint requests Harry R. Hill, Division of Clinical Immunology and Allergy, Department of Pediatrics, University of Utah, Salt Lake City, UT 84132.

Supported by U.S. Public Health Service Grants AI 19094 and AI 13150 and a grant from the Cystic Fibrosis Foundation.
The human neonate is uniquely susceptible to severe and overwhelming bacterial and fungal infections (1-9). While a number of abnormalities have been described in the host defense system of newborn infants $(7,8)$, one of the most important appears to be in PMN function. What reasons can be given for making this statement, in view of reports $(7,8)$ describing defects in almost every aspect of the immune system of the neonate? First is the type of infections that the neonate suffers. Skin infections with surface contaminants such as staphylococci and candida are extremely common in neonatal intensive care units and newborn nurseries (9). Clearly, PMNs are the first line of defense against this type of microbial invasion.

Second is the high incidence of pneumonia in neonates due to organisms such as group B streptococci (3). While macrophages play some role in the initial response to bacterial pulmonary infection, PMNs rapidly become the predominant cell type in the inflammatory exudate within the alveoli of adult patients with pneumonia (10). In contrast, there is a paucity of these cells in the alveoli of infants dying of group B streptococcal pneumonia (11). Along with antibody and complement, phagocytes are absolutely essential in killing of group B streptococci (12, 13). Clearly, the number and functional integrity of PMNs contributes to defense against this extremely common neonatal pathogen.

Third, systemic infection in the neonate, including sepsis and meningitis, is often more common and more severe when neutropenia is also present $(14,15)$. PMNs are often lacking or present in small numbers in the meninges of newborns with obvious bacterial meningitis or in the peripheral blood of infants with sepsis (14-16). These facts clearly point to abnormalities in PMNs contributing to the susceptibility of neonates to serious infection. The purpose herein will be to review and analyze the reported abnormalities in PMN function in neonates. In each case, an attempt will be made to assess the clinical importance of the abnormality and to define the structural and biochemical mechanisms involved. First we will review what is known about the biochemistry and function of PMNs from older children and adults. The activity of cells from neonates will then be compared and contrasted with that of normal cells. Lastly, I will speculate on the mechanisms involved in the observed abnormalities and discuss how they might interrelate.

\section{BIOCHEMISTRY AND FUNCTION OF NORMAL PMNS}

Activation. Activation is a term that is much more commonly applied to the macrophage when discussing the host defense system. Dorland's Medical Dictionary (17) defines "activation" as the "act or process of rendering something active." "Active," in turn, is defined as being "characterized by action, not passive, not expectant." Everything we know about the PMN suggests that it can be rendered active, not expectant and not passive, at 
least in the normal host. Recently, in a more limited scientific sense, activation of the PMN has come to mean those biochemical and physiological events which occur after chemotactic factor-receptor interaction (18). I suspect that the priming of the PMN for functional activity is dependent on these same biochemical and physiological changes in the cell. Furthermore, the priming is most certainly due to the interaction of the cell with inflammatory mediators derived from the invading microorganism, the complement system, arachidonic acid metabolism, or from other cells such as the macrophage or lymphocyte.

Chemotactic factor-receptor interaction and signal transduction. Receptors have been characterized for chemotactic factors, such as C5a and the formyl-peptides, on the surface of PMNs $(19,20)$. The number and affinity of these receptors on normal cells is known. Following ligand-receptor interaction, a complicated series of events occurs that subsequently results in functional activity. These events include changes in membrane potential (21-23), the breakdown of phosphoinositol into inositol triphosphate and diacyl-glycerol (24), an increase in free intracellular calcium ion $\left(\mathrm{Ca}^{++}\right)(23,25,26)$ provoked, in part, by inositol triphosphate, diacyl-glycerol-induced phosphokinase $\mathrm{C}$ activation (24), sodium ion $\left(\mathrm{Na}^{+}\right)$influx (27), alkalinization of the cytoplasm (28), and an increase in cell volume (27). Although, probably not directly involved in signal transduction of the PMN (29), there is also activation of adenylate cyclase and the generation of a transient elevation in cyclic $3^{\prime} 5^{\prime}$ adenosine monophosphate $(30,31)$. These events lead to a decrease in the net negative charge on the PMN cell membrane (32) and a ruffling of its surface.

Microtubules, microfilaments, and receptor mobilization. An area of cytoplasm at the outer margin of the cell, which is devoid of granules, assumes a glassy or hyaline appearance (33). This hyaline ectoplasm forms a broad lamellipodium at the leading edge of the cell; the cytoplasm appears to be very fluid in this area. Microfilaments ( $6 \mathrm{~nm}$ in diameter) appear in the ectoplasm which are composed of actin. These are especially prominent in areas where the cell attaches to the substrate. Larger, $24 \mathrm{~nm}$ diameter microtubules composed of tubulin, appear in the endoplasm of the cell and "insert" into the regions containing actin filaments. These structures probably assist in providing asymmetry and support for the contracting microfilaments (33). They are also clearly involved in degranulation and regulate the movement of receptors for certain lectins such as Con A on the surface of the PMN (34).

Adherence and aggregation. Recent evidence suggests that adherence of leukocytes to a substrate involves a series of surface glycoproteins (35-37). These glycoproteins share a common $\beta$ chain that has a molecular weight of approximately $94 \mathrm{kD}$. A glycoprotein termed Mol, which has an $\alpha$ chain of approximately $155 \mathrm{kD}$, is found on monocytes, granulocytes, and large granular lymphocytes. One domain of the molecule represents the receptor for C3bi. This glycoprotein not only functions to bind C3bicoated particles to the surface of PMNs but through another domain acts as a critical factor in adhesion related phenomena such as cell surface spreading, leukoaggregation, and cell movement (37). Another of these surface glycoproteins termed the human LFA-1, with an alpha chain of $180 \mathrm{kD}$, is found on all leukocytes and functions in lymphocyte adherence-dependent activities such as that of binding cytotoxic lymphocytes to target cells (37). A third glycoprotein of the same family, with an $\alpha$ chain of $150 \mathrm{kD}$, is termed Leu-M5 and has the same distribution as Mol but as yet no well documented function.

In addition to the surface glycoproteins involved in adhesion, one of the constituents of the specific granules, lactoferrin (38), also serves to promote attachment of PMNs to surfaces. Stimulation of PMNs with chemotactic factors or with the active ingredient of croton oil, phorbol myristate acetate, results in discharge of the specific granules and enhanced adherence. This is probably due both to the appearance of lactoferrin at the cell surface and to the upregulation of surface expression of a variety of receptors $(38,39)$.

PMNs may adhere to each other, a process termed aggregation, to inert surfaces or to endothelial cells $(40,41)$. Fibronectin, a high molecular weight glycoprotein $(450 \mathrm{kD})$ which is a major constituent of the intracellular matrix, is present on endothelial cells and involved in PMN attachment to these cells $(42,43)$. Stimulation of PMNs or the endothelial cells with chemotactic factors such as C5a or FMLP will result in enhanced adherence (41) or aggregation (40). The aggregation response of PMNs from normal adults to such stimulation is a temporary one, however, which is followed by disaggregation within a brief period of 2 to $3 \mathrm{~min}(40)$. Aggregation probably is a mechanism for amplification of the acute cellular response, since it results in the accumulation of a large number of phagocytes along the vessel wall nearest to the site of microbial invasion or injury. PMN aggregation can also be harmful, however, when it occurs diffusely throughout the vessels of the lung or other organs (44). Under these circumstances, diffuse endothelial cell damage may result from the generation of toxic oxygen radicals or the release of lysosomal enzymes by the adherent, aggregated PMNs.

Deformability and movement. After PMNs accumulate along the capillaries, they must deform and diapedese through the endothelium and vessel wall into the tissues. The ability of phagocytic cells to deform is critical not only in escaping the vascular system but also in moving through the tissues (45). To some extent the rigidity of the PMN is dependent on cytoskeletal elements such as the microtubules, microfilaments, and intermediate fibers. Contraction of the microfilaments and, thus deformability is an energy requiring process dependent on ATP. The process involves both actin filaments and myosin similar to the process of muscle contraction.

Movement of PMNs through tissues toward the site of microbial invasion or injury is dependent on a concentration gradient of chemotactic factor (46). The PMNs orient toward the gradient and begin to form lamellipodia as described above. These attach to a surface at the end toward the source of the chemotactic stimulus. Through the contraction of actin containing microfilaments, stabilized on a skeleton of microtubules, receptors at the leading edge of the cell migrate back toward the tail or uropod (47). The cytoplasm and organelles flow forward toward the "head" pulling most of the remainder of the cell along. Again, this appears to be an energy requiring process dependent upon ATP.

Phagocytosis. As the cell reaches the site of microbial invasion or injury, it no longer senses a concentration gradient of chemotactic factor but rather is surrounded by relatively high concentrations of mediators. At this point, directed movement probably ceases and receptors for the Fc fragment of immunoglobulin, breakdown products of the third component of complement (C3b and C3bi) and fibronectin upregulate $(39,48,49)$. There is some evidence that these receptors may even congregate at the "head" of the cell where they would be most likely to come in contact with an opsonized microbial invader (50).

Following contact of the opsonized particle with cell surface receptors for the $\mathrm{Fc}$ fragment of immunoglobulin or the receptors for the complement breakdown products $\mathrm{C} 3 \mathrm{~b}(\mathrm{CR}-1)$ or $\mathrm{C} 3 \mathrm{bi}$ (CR-3), the exterior membrane of the cell in the area of contact forms pseudopods that gradually surround the particle forming a phagocytic vacuole containing the offending pathogen. Recent evidence gathered with the aid of monoclonal antibodies to these receptors suggests that each may function independently or in concert to promote a certain proportion of the observed uptake of an opsonized particle or bacteria $(51,52)$. There is also evidence that fibronectin and fibronectin receptors on cells may function in this system to promote the association of opsonized particles with phagocytic cells (53-56).

Bactericidal activity. Following exposure of PMNs to opsonized particles or certain soluble stimuli, these cells undergo a 
marked change in the way in which they handle oxygen (57). This is termed the "respiratory burst" and is due to the activation of an NADPH oxidase at the cell surface (Fig. 1). This enzyme catalyzes the one electron reduction of oxygen to form superoxide $\left(\mathrm{O}_{2}{ }^{-}\right)$and $\mathrm{NADP}^{+}$. The NADP ${ }^{+}$stimulates glucose metabolism through the hexose monophosphae shunt, regenerating more $\mathrm{NADPH}$ to continue the respiratory burst. The $\mathrm{O}_{2}^{-}$is rapidly acted upon by superoxide dismutase to form hydrogen peroxide $\left(\mathrm{H}_{2} \mathrm{O}_{2}\right)$ and molecular oxygen. These intermediate products of the respiratory burst do not possess strong bactericidal activity themselves. Rather they are important in generating oxidized halogen and hydroxyl radicals as follows:

$$
\begin{gathered}
\mathrm{Cl}^{-}+\mathrm{H}_{2} \mathrm{O}_{2}- \\
\mathrm{O}_{2}^{-}+\mathrm{H}_{2} \mathrm{O}_{2}-\mathrm{OCl}^{-}+\mathrm{H}_{2} \mathrm{O} \\
-\mathrm{OH}^{-}+\mathrm{OH}^{-}+\mathrm{O}_{2}
\end{gathered}
$$

The first reaction is catalyzed by the lysosomal enzyme myeloperoxidase while the second requires iron or copper. Both the hypochlorite and hydroxyl radicals possess potent bactericidal activity.

Several mechanisms function within the cell to inactivate or detoxify the products of the respiratory burst (58). Catalase functions to breakdown hydrogen peroxide, while superoxide is acted upon by superoxide dismutase. Reduced glutathione also interacts with hydrogen peroxide in the presence of glutathione peroxidase as follows:

$$
2 \mathrm{GSH}+\mathrm{H}_{2} \mathrm{O}_{2}-------\mathrm{GSSG}+2 \mathrm{H}_{2} \mathrm{O}
$$

These mechanisms serve to protect the PMNs of normal adults from autooxidative damage caused by toxic products of the respiratory burst.

In addition to the oxygen dependent bactericidal mechanisms there are a number of oxygen-independent ones (59). These include lactoferrin, a component of specific granules mentioned earlier, which binds iron avidly and thus is active against organisms that require iron for growth. This substance in combination with iron also catalyzes the generation of hydroxyl radicals as shown above in formula 2. A number of cationic proteins, found primarily in azurophilic or secondary granules, also exist that contribute to oxygen-independent bactericidal activity. These bind to the surface of negatively charged, gram-negative organisms and inhibit growth. Permeability promoting factors have also been described. Lysozyme, contained in both primary and secondary granules, acts to disrupt peptidoglycans of the cell wall of gram positive organisms. In addition, lowered $\mathrm{pH}$ within the phagocytic vacuole contributes to the death of ingested pathogens.

With these basic facts about the biochemistry and function of normal PMNs in mind, lets proceed to an examination of the reported abnormalities in the PMNs of neonates.

\section{ABNORMALITIES IN NEONATAL POLYMORPHONUCLEAR LEUKOCYTES}

Activation. A variety of processes appears to be able to prime or "activate" the PMNs of older children and adults. These include systemic $(60,61)$, pulmonary $(62)$, and even localized skin infection (63). The PMNs of patients with the adult respiratory distress syndrome (64) and individuals after myocardial infarction are also in an activated state (65). These cells respond in an enhanced fashion in chemotactic and aggregation assays and in assays designed to assess the respiratory burst. Enhanced adherence by PMNs from adult patients with sepsis has also been described (66). Exposure of normal PMNs from adults to low concentrations of chemotactic factors including formyl-methionyl-leucyl-phenylalanine and activated complement components can result in similar functional and metabolic alterations in vitro $(41,67,68)$. Thus, the cells of normal mature individuals appear to have a "reserve" that can be called on during times of stress. This does not appear to be the case with the PMNs of neonates. Wright et al. (69) first observed that the PMNs of stressed neonates with a variety of infectious and noninfectious illnesses had depressed bactericidal activity when compared to control health infants. We subsequently also observed that the PMNs of stressed infants had decreased respiratory burst activity upon exposure to a phagocytizable particle and decreased bactericidal activity for group B streptococci $(70,71)$. This abnormality could not be ascribed to a decrease in phagocytic uptake (70-72).

We have preliminary data suggesting that preexposure of the PMNs of neonates to low levels of chemotactic factors does not result in enhanced motility or enhanced respiratory burst activity as has been described with the PMNs of adults (67). The reasons for this are currently not known. One possibility is related to the generation of $\mathrm{LTB}_{4}$ by the PMNs of neonates (73). This substance has potent PMN activating properties. Since it is produced by PMNs upon stimulation with chemotactic factors such as $\mathrm{C5}_{\mathrm{a}}$ and FMLP, it may serve as an intra- or intercellular second messenger. However, Kikawa et al. (73) found that cord blood PMNs and those from infants produce normal amounts of $\mathrm{LTB}_{4}$

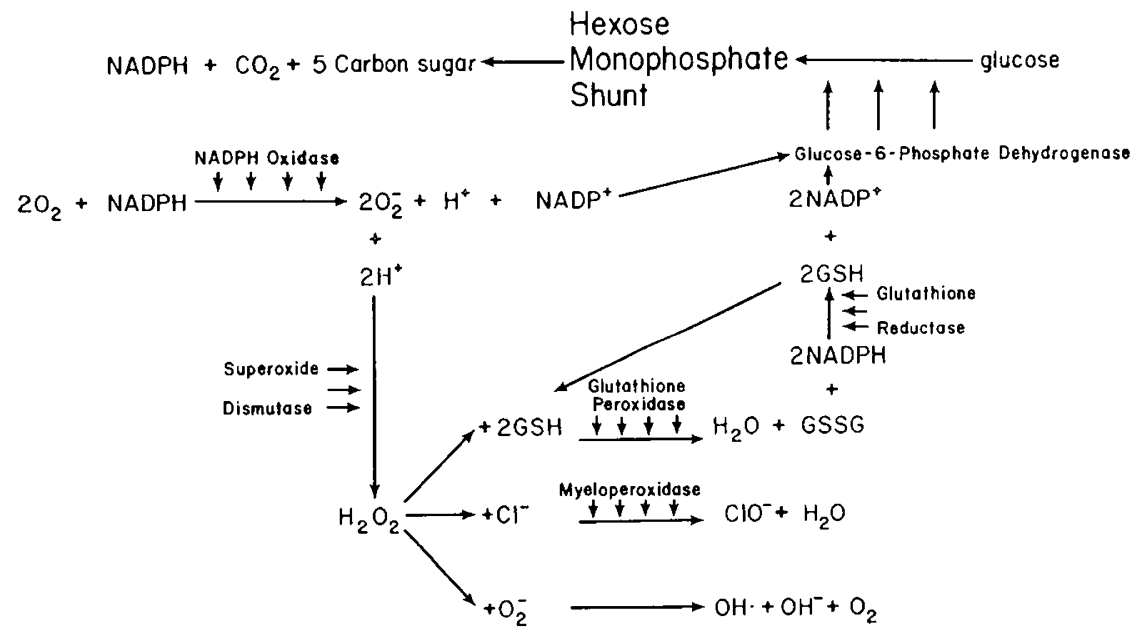

Haber-Weiss Reaction

Fig. 1. The respiratory burst in human polymorphonuclear leukocytes. Reprinted with permission from Pediatr Clin North Am 27:805-830, 1980. 
when exposed to PAF or the calcium ionophore A23187. Thus, decreased ability to produce $\mathrm{LTB}_{4}$ is not the reason for the lack of activation of the PMNs of neonates. $\mathrm{LTB}_{4}$ production following chemotactic factor stimulation of neonatal PMNs has not been studied, however.

Chemotactic factor-receptor interaction and signal transduction. Additional possible reasons for failure of the PMNs of neonates to "activate" lie in chemotactic factor-receptor interaction or the mechanisms for stimulus response coupling. Anderson et al. (47) reported that the PMNs of neonates have a normal number of receptors for tritiated FMLP, and that the affinity of the binding and dissociation at $37^{\circ} \mathrm{C}$ is equivalent to that of PMNs from adults. Strauss and Snyder (74) also reported that the binding of FMLP to PMNs from neonates was normal at both 22 and $4^{\circ} \mathrm{C}$, and that the affinity of the binding was normal at both temperatures. Based on the results of their studies, these authors suggested that the abnormality in the neonatal cell involved events subsequent to initial chemotactic factor-receptor interaction. Subsequently, we confirmed that FMLP binding was normal on the PMNs of neonates at not only $37^{\circ} \mathrm{C}(23)$ but also at $0^{\circ} \mathrm{C}$ where receptor-ligand internalization would be minimized (75). We also studied events subsequent to chemotactic factor receptor interaction in the PMNs of neonates. Employing the calcium-sensitive probe Quin 2/AM, we (23) found that the level of free calcium reached within the PMNs of neonates was lower than that of the PMNs from adults following chemotactic factor stimulation (Fig. 2). The increase in free calcium following chemotactic factor stimulation apparently came predominantly from intracellular stores since similar increases occurred in media deprived of calcium. These results are similar to those of Korchak et al. $(18,76)$ who demonstrated that the activation of PMNs is at least partially dependent upon increases in free intracellular calcium that is derived primarily from intracellular pools. It should be pointed out that Strauss and Nyder (77) have indicated that chemotactic factors elicit a normal influx of calcium in the PMNs of neonates. This does not necessarily conflict with our data, however, since we measured free intracellular levels of calcium derived primarily from intracellular pools.

Following cellular activation and increases in free intracellular calcium, an ATP-dependent calcium pump is activated in the plasma membrane of human PMNs that pumps calcium from the cytoplasm to the external surface (78). Activation of this pump is dependent on the level of free calcium reached within the cell. Calmodulin also stimulates this pump by increasing the affinity of $\mathrm{Ca}^{++}$for the pump. Korchak and Weissman (79), employing the $\mathrm{TPMP}^{+}$, have shown that surface stimulation of
PMNs results in a rapid depolarization followed by slow hyperpolarization response. Seligmann and Gallin (21) have indicated that the depolarization is most likely associated with activation of the respiratory burst since it is reduced to absent in the PMNs of patients with chronic granulomatous disease. This initial depolarization can be produced by exposure of cells to the calcium ionophore A23187 and to PMA, which stimulate oxidative metabolism but not directed movement. In contrast, the subsequent hyperpolarization was attributed to an increase in permeability to potassium (80).

In addition to measuring free calcium levels within the PMNs of neonates, we also assessed changes in membrane potential employing the potential sensitive dye $\mathrm{DiOC}_{5}(3)$. We (23) found that the PMNs of neonates with defective chemotactic function failed to show the hyperpolarization response observed following chemotactic factor stimulation of PMNs from adults (Fig. 3). Treatment of adult PMNs with the calcium channel blocking agent, verapamil, resulted in a response similar to that observed with PMNs from neonates. We are currently attempting to study potassium flux in these cells and to also assess the ATP-dependent calcium pump. We are also studying ATP levels in neonatal PMNs as monocytes from infants have been reported to have low levels of this critical energy source (81). Thus, both an

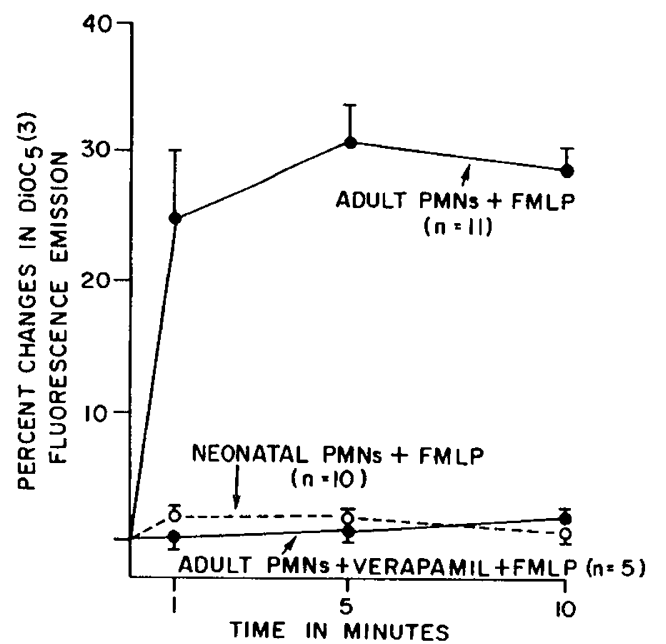

Fig. 3. Membrane potential changes in FMLP-stimulated adult and neonatal PMNs as measured by changes in $\operatorname{DiOC}_{5}(3)$ fluorescence. Reprinted with permission from J Exp Med 160:1247-1252, 1984.
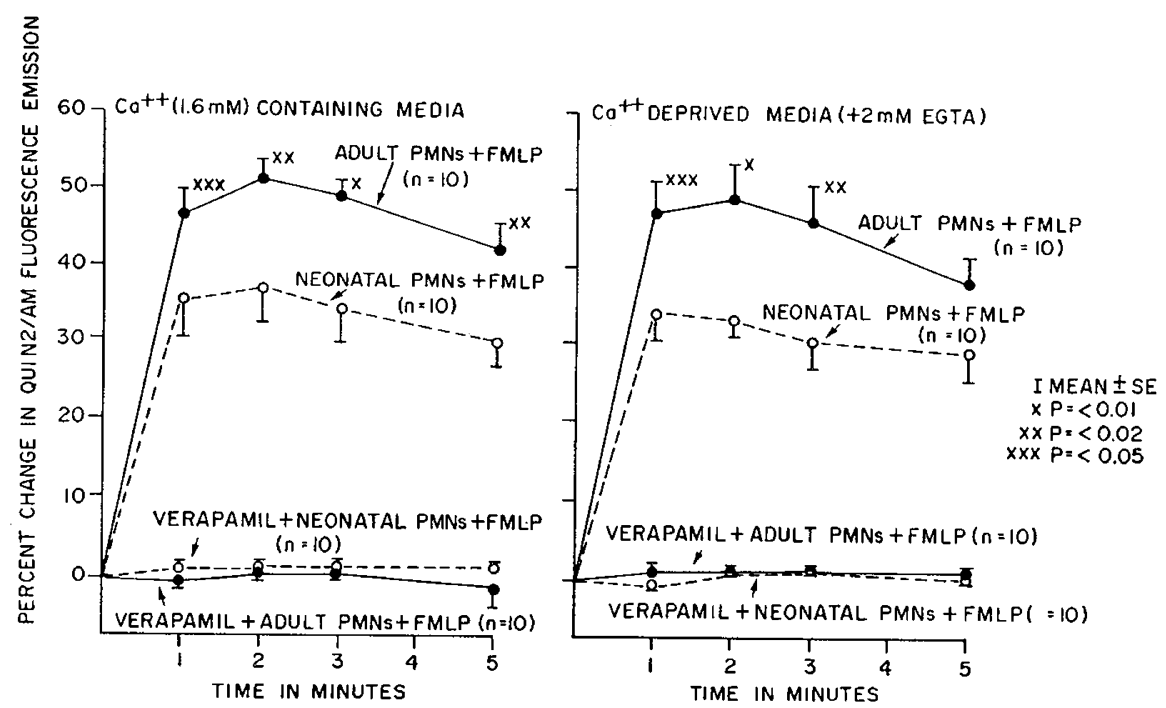

Fig. 2. Changes in intracellular free calcium in FMLP stimulated adult and neonatal PMNs as measured by Quin 2/AM fluorescence. Reprinted with permission from J Exp Med 160:1247-1252, 1984. 
insufficient rise in intracellular free $\mathrm{Ca}^{++}$and low ATP levels could lead to inadequate pumping of $\mathrm{Ca}^{++}$back to the exterior in the PMNs of neonates. This, along with alterations in $\mathrm{K}^{+}$flux, might contribute to the lack of the hyperpolarization response in the neonatal PMN. The relationship of this defect to functional activity remains to be determined, but it is likely that this represents an abnormality in signal transduction. Further evidence of this abnormality has come from studies on the generation of the chemotactic factor-induced rise in cAMP. We have found that the PMNs of neonates fail to produce an increase in cAMP after stimulation with FMLP (75). While this may not actually be related to the defect in PMN activation observed (29), it does indicate that the signal is not being transduced appropriately.

Microtubules, microfilaments, deformability, and receptor mobilization. Miller $(82,83)$ has indicated that the PMNs of the newborn fail to deform normally following chemotactic factor stimulation. Furthermore, Kimura et al. (84) and Strauss and Hart (85) have shown that these cells do not mobilize surface receptors for Con A following microtubule disruption with colchicine. These investigators postulated that the infants' PMNs possessed rigid cytoskeletal elements that prevented adequate deformability and movement. More recently, we $(75,86,87)$ have made similar observations. Although, we did observe an increase in Con A capping following exposure at the PMNs of neonates to colchicine, the levels reached were significantly less than that observed in adult cells. We interpret this to mean that elements other than the microtubules themselves are involved in making the cell a rigid one $(75,86,87)$.

Deformability and movement of PMNs, as mentioned, is dependent in part on the formation of filamentous actin (F actin) from gel actin. Contraction of the microfilaments is dependent on an ATP-dependent interaction of the F actin with myosin. Employing the fluorescent probe NBD-phallacidin which binds specifically to F actin, we (88) and Harris et al. (89) have reported decreased generation of $F$ actin by the PMNs of neonates following chemotactic factor stimulation. Hilmo and Howard (90) reported that the relative increase in $\mathrm{F}$ actin content of neonatal cells was less than that of PMNs from adults following FMLP stimulation, but this was due to a higher baseline $F$ actin content in the PMNs from infants. Thus, it does not appear that the overall level of $\mathrm{F}$ actin is less in the PMNs of neonates. A deficiency of cellular ATP might also impair contraction of microfilaments due to the requirement for this energy source to promote the interaction of actin with myosin.

Evidence of impaired movement of surface receptors has also come from studies of Anderson et al. (47) and Roberts and Stiehm (91). These investigators found that receptors for latex beads (47) or Con A (91) failed to redistribute from the head to the tail or uropod of migrating PMNs. Anderson et al. (47) suggested that the abnormality they observed lay in reduced modulation of cell adhesiveness by the PMNs of neonates. These authors found that the PMNs of neonates fail to adequately upregulate adhesive Mol, or CR-3, receptors on their surface following chemotactic factor stimulation (92). This is in spite of the fact that the neonatal cells possess total amounts of the Mol receptor that are equivalent to that found on the PMNs of adults (93). These investigators localized the intracellular stores of these receptors within the PMNs of adults and neonates and suggested that decreased upregulation may be due to abnormal translocation of Mol from one or more intracellular pools to the cell surface (93). Anderson et al. (94) also reported that the PMNs of neonates failed to orient normally or assemble microtubules appropriately in a chemotactic gradient. Each of these abnormalities could be due, of course, to abnormal signal transduction. The functional consequences of the above abnormalities include neonatal PMNs that orient, adhere, and move poorly $(47,88$, 93-96).

Adherence and aggregation. Neonatal PMN also adhere poorly to surfaces according to most reports $(43,47,96)$. This has been attributed both to failure to upregulate the surface expression of adhesive glycoproteins $(92,93)$ and to decreased fibronectin $(43)$. Olson et al. (40) reported that FMLP- or C5a-induced aggregation of PMNs from neonates was slower than that in adults. More importantly, the cells failed to undergo a disaggregation response similar to that of PMNs from adults. These authors speculated that defective chemotaxis might result in vivo from the inability of the cells to undergo this disaggregation response. Interestingly, these same authors reported that PHA-induced aggregation was actually decreased by the PMNs of neonates (98). There is suggestive evidence that PMN aggregation occurs in the lungs of neonates which may lead to pulmonary damage. Recently, we have found that a group B streptococcal type III antigen in the presence of serum promotes PMN aggregation and adherence to endothelial cells (99). Patients dying of group B streptococcal pneumonia often have such aggregates in capillaries throughout their lung. This may be due, in part, to the irreversible aggregatory response of the neonatal cell.

All of the abnormalities described above result in a slow influx of PMNs to the site of inflammation or microbial invasion. This results, most likely, in the neonate's enhanced susceptibility to skin infections, abscesses, mucocutaneous candida infections, and pneumonia. This, in my opinion, is one of the most important host defense abnormalities in the neonate since it predisposes to serious and often overwhelming bacterial infection.

Phagocytosis and bactericidal activity. When the PMN reaches the site of invasion, it must prepare to ingest the offending pathogen. If the particle is adequately opsonized with antibody and complement, phagocytosis proceeds through receptors on the PMN surface for the Fc fragment of immunoglobulin or the complement components $\mathrm{C} 3 \mathrm{~b}$ (CR-1 receptor) and C3bi (CR-3 or Mol) (51, 52). Pross et al. (100), employing rosetting techniques, reported that cord blood PMNs have FC and C3b receptors equal in number to those on PMNs from adults. These results were confirmed by Marodi et al. (101). More recently, Bruce et al. (48) employed monoclonal antibodies and flow cytometry to examine C3b (CR-1) and C3bi (CR-3; Mol) receptors on the surface of PMNs from adults and neonates. In the resting state at 0 and $37^{\circ} \mathrm{C}$, there was no difference in expression of either receptor on neonatal versus adult cells. However, the stress of vaginal labor did result in a modest upregulation of the receptors on the PMNs of neonates. When isolated PMNs were stimulated with FMLP or C5a, the neonatal cells upregulated their C3bi (CR-3; Mol) receptors but to only $75 \%$ of the levels observed on stimulated PMNs from adults. Similar results have been reported by Anderson et al. (92). Thus, both adherence, movement, and ingestion of $\mathrm{C} 3 \mathrm{bi}$-coated particles may be somewhat impaired in the "activated" PMNs of neonates.

Phagocytosis, or actual particle ingestion, by the PMNs of human neonates has been studied by a number of investigators (69-72, 101-104). Miller (102) reported that the uptake of yeast by the PMNs of neonates was less than that by PMNs from adults. This was especially true when the plasma in the system used to supply opsonins was present at a concentration of less than $2.5 \%$. Two other conditions of the assay employed by Miller (102) might aid in explaining the observed abnormality. First, yeast are very large particles when compared to bacteria. Ingestion of such a large object is more akin to cell movement than phagocytosis since a pseudopod must be thrown out to surround and engulf the yeast cell. Second, the PMNs were stressed in vitro by being challenged with 100 yeast cells per PMN. The neonatal cells were obviously pushed to their limits and were defective in their ability to ingest these particles.

Dossett et al. (103), employing Staphylococcus aureus and Escherichia coli opsonized in a higher concentration of pooled adult serum, found that the phagocytic and bactericidal capacity of PMNs from newborns was not different from that of controls. Forman and Stiehm (104) also reported normal phagocytosis by the PMNs of 15 term and 13 of 14 preterm well neonates. In a group of six of nine stressed ill infants, however, phagocytosis 
and intracellular killing were abnormal. McCracken and Eichenwald (105) reported normal phagocytosis and killing of a variety of bacterial pathogens by neonatal PMNs when adult opsonins were utilized. Subsequently, Wright et al. (69) examined the functional capacity of the PMNs from 40 sick newborns and found that $25(63 \%)$ had decreased bactericidal activity for $S$. aureus and decreased phagocytic or bactericidal activity for $E$. coli. No consistent correlation was found between the observed abnormalities and birth weight, gestational age, or specific diagnosis leading to the "stress." Employing a radiolabeled bacterial uptake assay, we $(70,71)$ found that PMNs from both normal and "stressed" ill infants phagoctyized opsonized group B streptococci normally. In contrast, four of five stressed infants examined had PMN bactericidal defects for group B streptococci. Harris et al. (72) also found that stressed infants' PMNs ingested radiolabeled group B streptococci normally.

When all of the studies are taken into account, the consensus would have to be that the PMNs of well term and probably preterm infants have normal phagocytic and bactericidal activity. If the cells are "stressed" in vitro or in vivo phagocytic activity for gram positive bacteria remains intact, while bactericidal activity for both gram positive and gram-negative organisms is decreased. Phagocytosis of large yeast particles (102) and some gram negative bacteria may also be impaired (69).

The reason for the decrease in PMN bactericidal activity of "stressed" neonates is not completely understood $(69-72,104)$. Shigeoka et al. $(70,71)$ found decreased CL responses to opsonized particles by the PMNs of stressed neonates, as well as decreased bactericidal activity for group B streptococci. In contrast, the CL responses to soluble stimuli such as PMA were actually enhanced with the PMNs of these "stressed" patients. We postulated that this represented a defect in the later portions of the respiratory burst and that defective function might be due to autooxidative cell damage since antioxidants partially corrected the abnormality. Strauss and Snyder (106) subsequently showed that PMNs from human neonates actually have a more readily activated superoxide generating system than do PMNs of adults. Additional studies by Strauss and colleagues $(58,107)$ showed that neonatal PMNs had decreased levels of glutathione, glutathione peroxidase, and catalase. These authors also showed that neonatal PMNs released more hydrogen peroxide in the resting state than did PMNs from adults. Furthermore, the PMNs from neonates had decreased viability, most likely due to peroxidative cell damage and death.

The question then arises "Why is there a defect in bactericidal activity in the PMNs of 'stressed' neonates when the respiratory burst has an enhanced ability to be activated and generate superoxide and hydrogen peroxide?" Ambruso et al. (109, 110) have provided a likely explanation for this phenomenon. These authors found that neonatal PMNs have a discrepancy in the ability to produce superoxide and hydroxyl radical. Following stimulation of neonatal PMNs with either opsonized zymosan or PMA, the generation of. $\mathrm{OH}$ was relatively less than the production of $\mathrm{O}_{2}^{-}$. Furthermore, the content of lactoferrin within the granules of neonatal PMNs was moderately decreased compared to that in cells from adults. Lactoferrin, which resides within the specific granules, acts to enhance the generation of hydroxyl radical, a more potent microbicidal agent than either superoxide or hydrogen peroxide. Electromicroscopic studies demonstrated decreased specific granule content within PMNs of neonates (110). This may well explain the paradox of decreased microbicidal activity in the presence of normal to increased respiratory burst activity in the PMNs of neonates.

The possibility of autooxidative cell damage, which could also affect cytoskeletal elements, being important in the pathogenesis of the defects in the PMNs of neonates has led investigators to try to correct the abnormalities with antioxidants. We (71) found that $\mathrm{D}-\alpha$-tocopherol (vitamin $\mathrm{E}$ ) or the 2,3 dihydroxybenzoic acid treatment of "stressed" neonatal PMNs resulted in more normal respiratory burst activity in response to particulate or soluble

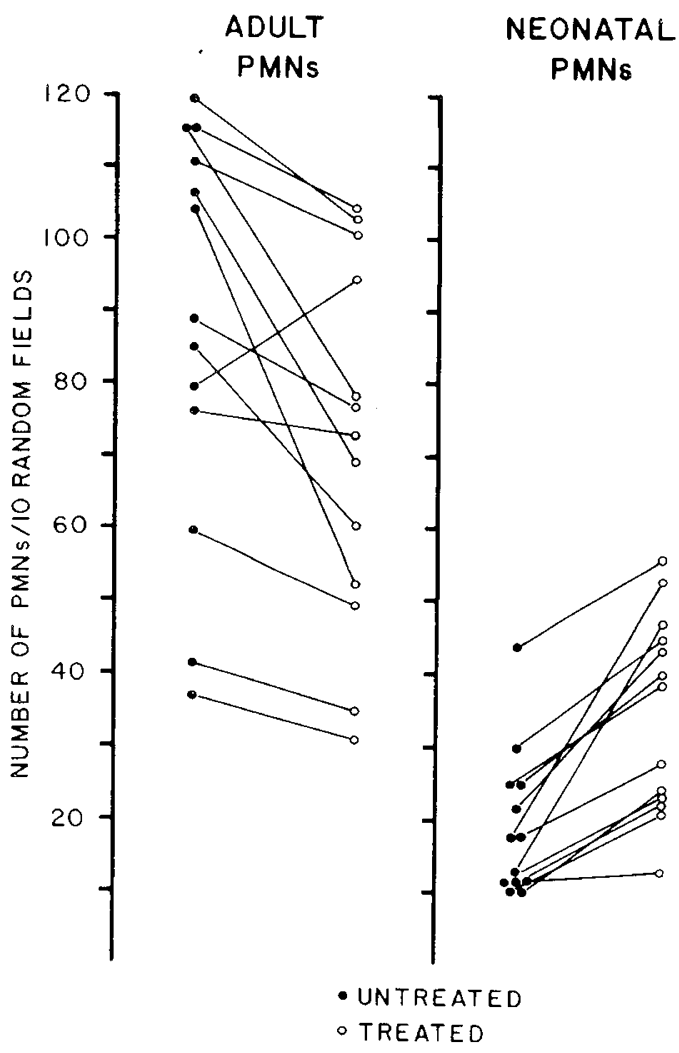

Fig. 4. Effect of pentoxifylline on FMLP-stimulated chemotactic responses of PMNs from adults and neonates.

stimuli. Chirico et al. (111) also reported that vitamin E therapy improved abnormal PMN function in premature infants.

Recently, we have explored another potential therapeutic agent, pentoxifylline (75). This compound is a methylxanthine derivative which has been used to treat cerebrovascular and peripheral vascular disease (112). The compound has been reported to enhance erythrocyte and leukocyte deformability (113115 ) and to increase ATP levels within cells (116). We have found that low concentrations of this drug improve signal transduction in the PMNs of neonates and at least partially correct the observed abnormality in membrane potential change and cAMP generation (75). As shown in Figure 4, pentoxifylline enhanced the chemotactic response of PMNs from neonates while having little, or even a depressive, effect on the response of PMNs from adults. More recently, we $(86,87)$ have shown that the drug also alters the mobility of Con A receptors on colchicine-treated PMNs of neonates. This suggests the possibility of pharmacologic modification of this developmental defect in cell motility. It is my honest opinion, that only through such attempts to enhance the host defense system of the neonate, will we continue to lower the morbidity and mortality from infectious disorders in the human neonate.

Acknowledgments. Special thanks to Deborah Camomile for secretarial aid, to Drs. Allen Newton and Ann Shigeoka for their work on these studies, to Nancy Augustine and Betsy Morris for technical assistance, and to Don Morse for his art work.

\section{REFERENCES}

1. Santos JI, Hill HR 1982 Bacterial infections of the neonate. In: Wedgwood RJ, Davis RD, Ray CG, Kelley VC (eds) Infections in Children. Harper and Row, Philadelphia, pp 179-202

2. Hill HR 1985 Diagnosis and treatment of sepsis in the neonate. In: Root RK, Sande MA (eds) Septic Shock: Contemporary Topics in Infectious Diseases. Churchill Livingstone, New York, pp 219-232

3. Hill HR 1984 Group B streptococcal infections. In: Holmes KK, Mardh PA Sparling PF, Wiesner PJ (eds) Sexually Transmitted Diseases. McGraw Hill, 
New York, pp 397-407

4. Hill HR, Christensen RD 1987 Neonatal sepsis: a review of new treatment methods. In: Guthrie RD (ed) Neonatal Critical Care: Clinics in Critical Care Medicine, Vol 13. Churchill Livingstone, New York, pp 251-269

5. Siegel JD, McCracken GH 1981 Sepsis neonatorum. N Engl J Med 304:642647

6. Klein JO 1984 Recent advances in management of bacterial meningitis in neonates. Infection 12(suppl):S44-S48

7. Hill HR 1985 Host defense in the neonate: prospects for enhancement. Semin Perinatol 9:2-11

8. Wilson CB 1986 Immunologic basis for increased susceptibility of the neonate to infection. J Pediatr 108:1-12

9. Hemming VG, Overall JC Jr, Britt MR 1976 Nosocomial infections in a newborn intensive care unit. N Engl J Med 294:1310-1316

10. Henson PM, Larsen GL, Henson JE. Newman SL, Musson RA, Leslie CC 1984 Resolution of pulmonary inflammation. Fed Proc 43:2799-2806

11. Katzenstein A, Davis C, Braude A 1976 Pulmonary changes in neonatal sepsis due to group B beta-hemolytic streptococcus: relation to hyaline membrane disease. J Infect Dis 133:430-435

12. Shigeoka AO, Hall RT, Hemming VG, Allred CD, Hill HR 1978 Role of antibody and complement in opsonization of group B streptococci. Infect Immun 21:34-40

13. Baltimore RS, Kasper DL, Baker CJ, Goroff DK 1977 Antigenic specificity of opsonophagocytic antibodies in rabbit antisera to group B streptococci. J Immunol 118:673-678

14. Christensen RD, Shigeoka AO, Hill HR, Rothstein G 1980 Neutropenia and bone marrow exhaustion in human and experimental neonatal sepsis. Pediatr Res 14:806-808

15. Christensen RD, Rothstein G 1980 Exhaustion of mature marrow neutrophils in neonates with sepsis. Pediatrics 96:316-318

16. Howard JB, McCracken GH Jr 1974 The spectrum of group B streptococcal infections in infancy. Am J Dis Child 128:815-818

17. Dorland's Illustrated Medical Dictionary 1974 WB Saunders, Philadelphia, pp 33

18. Korchak HM, Rutherford L.E, Weissmann G 1984 Stimulus response coupling in the human neutrophil. I. Kinetic analysis of changes in calcium permeability. J Biol Chem 259:4070-4075

19. Chenoweth DE, Hughi TE 1978 Demonstration of specific C5a receptor on intact human polymorphonuclear leukocytes. Proc Natl Acad Sci USA 75:3943-3947

20. Williams LT, Snyderman R, Pike MC, Lefkowitz RJ 1977 Specific receptor sites for chemotactic peptides on human polymorphonuclear leukocytes. Proc Natl Acad Sci USA 74:1204-1208

21. Seligmann BE, Gallin J1 1980 Use of lipophilic probes of membrane potential to assess human neutrophil activation. $\mathbf{J}$ Clin Invest 66:493-503

22. Mottola C, Romeo D 1982 Calcium movement and membrane potential changes in the early phase of neutrophil activation by phorbol myristate acetate: a study with ion-selective electrodes. J Cell Biol 93:129-134

23. Sacchi F, Hill HR 1984 Defective membrane potential changes in neutrophils from human neonates. J Exp Med 160:1247-1252

24. Berridge MJ, Irvine RF 1984 Inositol triphosphate, a novel second messenger in cellular signal transduction. Nature 312:315-321

25. White JR, Naccache PH, Molski TFP, Borgeat P, Sha'afi RI 1983 Direct demonstration of increased intracellular concentrations of free calcium in rabbit and human neutrophils following stimulation by chemotactic factors. Biochem Biophys Res Commun 113:44-50

26. Skylar LA, Oades AG 1985 Signal transduction and ligand-receptor dynamics in the neutrophil: $\mathrm{Ca}^{2+}$ modulation and restoration. $\mathrm{J} \mathrm{Biol} \mathrm{Chem} \mathrm{600:11468-}$ 11475

27. Grinstein S, Furuya W, Cragoe EJ Jr 1986 Volume changes in activated human neutrophils: The role of $\mathrm{Na}^{+} / \mathrm{H}^{+}$exchange. J Cell Physiol 128:33-40

28. Simchowitz L Cragoe EJ Jr 1986 Regulation of human neutrophil chemotaxis by intracellular $\mathrm{pH}$. J Biol Chem 261:6492-6500

29. Verghese MW, Fox K, McPhail LC, Snyderman R 1985 Chemoattractantelicited alterations of cAMP levels in human polymorphonuclear leukocytes require a $\mathrm{Ca}^{2+}$-dependent mechanism which is independent of transmembrane activation of adenylate cyclase. J Biol Chem 260:6769-6775

30. Simchowitz L, Fischbein LC, Spilberg I, Atkinson JP 1980 Induction of a transient elevation in intracellular levels of adenosine $3^{\prime} 5^{\prime}$-cyclic monophosphate by chemotactic factor: an early event in human neutrophil activation. J Immunol 124:1482-1491

31. Jackowski S, Sha'afi RI 1979 Response of adenosine cyclic 3'5'-monophosphate level in rabbit neutrophils to the chemotactic peptide formyl-methionyl-leucyl-phenylalanine. Mol Pharmacol 16:473-481

32. Gallin JI 1980 Degranulating stimuli decrease the negative surface charge and increase the adhesiveness of human neutrophils. J Clin Invest 65:298-306

33. Stossel TP 1974 Phagocytosis. N Engl J Med 290:717-723

34. Albertini DF, Berlin RD, Oliver JM 1977 The mechanism of concanavalin A cap formation in leukocytes. J Cell Sci 26:57-75

35. Todd RF, Arnaout MA, Rosen RE, Crowley CA, Peters WA, Babior BM 1984 Subcellular localization of the large subunit of Mol, a surface glycoprotein associated with neutrophil adhesion. J Clin Invest 74:1280-1290

36. Gallin J 1985 Leukocyte adherence-related glycoproteins LFA-1, Mol and p150,95: a new group of monoclonal antibodies, a new disease, and a possible opportunity to understand the molecular basis of leukocyte adherence. J Infect Dis 152:661-664

37. Dana N, Styrt B, Griffin JD, Todd RF III, Klempner MS, Arnaout MA 1986
Two functional domains in the phagocyte membrane glycoprotein Mol identified with monoclonal antibodies. J Immunol 137:3259-3263

38. Oseas R, Yang HH, Baehner RL, Boxer LA 1981 Lactoferrin: a promoter of polymorphonuclear leukocyte adhesiveness. Blood 57:939-945

39. Fletcher MP, Seligmann BE, Gallin JI 1982 Correlation of human neutrophil secretion, chemoattractant receptor mobilization, and enhanced functional capacity. J Immunol 128:941-948

40. Olson TA, Ruymann FB, Cook BA, Burgess DP, Henson SA, Thomas PJ 1983 Newborn polymorphonuclear leukocyte aggregation: a study of physical properties and ultrastructure using chemotactic peptides. Pediatr Res 17:993-997

41. Zimmerman GA, Hill HR 1984 Inflammatory mediators stimulate granulocyte adherence to cultured human endothelial cells. Thromb Res 35:203217

42. Mosesson MW, Amrani DL 1980 The structure and biologic activities of plasma fibronectin. Blood 56:145-158

43. Harris MC, Levitt J, Douglas SD, Gerdes JS, Polin RA 1985 Effect of fibronectin on adherence of neutrophils from newborn infants. $J$ Clin $\mathrm{Mi}$ crobiol 21:243-246

44. Jacob HS, Craddock PR, Hammerschmidt DE, Moldow CF 1980 Complement-induced granulocyte aggregation. An unsuspected mechanism of disease. N Engl J Med 302:789-794

45. Kawaoka EJ, Miller ME, Cheung ATW 1981 Chemotactic factor-induced effects upon deformability of human polymorphonuclear leukocytes. J Clin Immunol 1:41-44

46. Schiffman E, Showell HV, Corcoran BA, Ward PA, Smith E, Becker EL 1975 The isolation and partial characterization of neutrophil chemotactic factors from Escherichia coli. J Immunol 114:1831-1837

47. Anderson DC, Hughes BJ, Smith CW 1981 Abnormal mobility of neonatal polymorphonuclear leukocytes: Relationship to impaired redistribution of surface adhesion sites by chemotactic factor or colchicine. J Clin Invest 68:863-874

48. Bruce MC, Baley JE, Medvik KA, Berger M 1987 Impaired surface membrane expression of $\mathrm{C} 3 \mathrm{bi}$ but not $\mathrm{C} 3 \mathrm{~b}$ receptors on neonatal neutrophils. Pediatr Res 21:306-311

49. Spagnuolo PJ, Lederman MM. Schiltz J, Ellner J, Culp L 1982 A possible role for cold insoluble globulin in chemotactic factor mediated polymorphonuclear leukocyte adherence to plastic. Biochem Biophys Res Commun $106: 471-478$

S0. Walter RJ, Berlin RD, Oliver JM 1980 Asymmetric Fc receptor distribution on human PMN oriented in a chemotactic gradient. Nature 286:724-725

51. Gordon DL, Johnson GM, Hostetter MK 1986 Ligand-receptor interactions in the phagocytosis of virulent Streptococcus pneumoniae by polymorphonuclear leukocytes. J Infect Dis 154:619-626

52. Hostetter MK 1986 Serotype variations among virulent pneumococci in deposition and degradation of covalently bound C3b: Implications for phagocytosis and antibody production. J Infect Dis 153:682-693

53. Bevilacqua MP, Amrani D, Mosesson DW, Bianco C 1981 Receptors for cold-insoluble globulin (plasma fibronectin) on human monocytes. J Exp Med 153:42-60

54. Proctor RA, Prendergast E, Mosher DF 1982 Fibronectin mediates attachment of Staphylococcus aureus to human neutrophils. Blood 59:681-687

55. Hill HR, Shigeoka AO, Augustine NH, Pritchard D, Lundblad JL, Schwartz RS 1984 Fibronectin enhances the opsonic and protective activity of monoclonal and polyclonal antibody against group B streptococci. J Exp Med 159:1618-1628

56. Jacobs RF, Kiel DP, Sanders ML, Steele RW 1985 Neonatal macrophage phagocytosis of group B streptococci III: enhancement by fibronectin and gammaglobulin. J Infect Dis 152:695-700

57. Babior BM 1984 The respiratory burst of phagocytes. J Clin Invest 73:599 601

58. Strauss RG, Snyder EL, Wallace PD, Rosenberger TG 1980 Oxygen-detoxifying enzymes in neutrophils of infants and their mothers. J Lab Clin Med 95:897-904

59. Boxer GJ, Curnutte JT, Boxer LA 1985 Polymorphonuclear leukocyte function. Hosp Pract 3:69-90

60. Hill HR, Gerrard J, Hogan NA, Quie PG 1974 Hyperactivity of neutrophil leukotactic responses during active bacterial infection. J Clin Invest 53:9961002

61. Barbour AG, Allred CD, Solberg CO, Hill HR 1980 Chemiluminescence production by granulocytes from patients with active bacterial infection. Infect Dis 141:14-26

62. Hill HR, Warwick WJ, Dettloff J, Quie PG 1974 Neutrophil granulocyte function in patients with pulmonary infections. J Pediatr 84:55-58

63. Hill HR, Kaplan EL, Dajani A, Wannamaker LW, Quie PG 1974 Leukotactic activity and reduction of nitroblue tetrazolium by neutrophil granulocytes from patients with streptococcal skin infection. J Infect Dis 129:322-326

64. Zimmerman GA, Renzetti AD, Hill HR 1983 Functional and metabolic activity of circulating polymorphonuclear leukocytes from patients with adult respiratory distress syndrome. Am Rev Respir Dis 127:290-300

65. Chapman HA, Hill HR 1976 Enhanced neutrophil chemotactic responses following myocardial infarction. Clin Res 24:445A

66. Venezio FR, Westenfelder GO, Phair JP 1982 The adherence of polymorphonuclear leukocytes in patients with sepsis. J Infect Dis 145:351-357

67. McCall CE, Bass DA, DeChatelet LR, Link AS Jr, Mann M 1979 In vitro responses of human neutrophils to $\mathrm{N}$-formyl-methionyl-leucyl-phenylalanine: correlation with effects of acute bacterial infection. J Infect Dis 
140:277-286

68. Allred CD, Hill HR 1978 Effect of chemoattractants on chemiluminescence Infect Immun 19:833-838

69. Wright WC Jr, Ank BJ, Hebert J, Stiehm ER 1975 Decreased bactericidal activity of leukocytes of stressed newborn infants. Pediatrics 56:579-584

70. Shigeoka AO, Santos JI, Hill HR 1979 Functional analysis of neutrophil granulocytes from healthy, infected, and stressed neonates. J Pediatr 95:454460 .

71. Shigeoka AO, Charette RP, Wyman ML, Hill HR 1981 Defective oxidative metabolic responses of neutrophils from stressed neonates. J Pediatr 98:392398

72. Harris MC, Stroobant J, Cody CS, Douglas SD, Polin RA 1983 Phagocytosis of group B streptotoccus by neutrophils from newborn infants. Pediatr Res 17:358-361

73. Kikawa Y, Shigematsu Y, Sudo M 1986 Leukotriene $B_{4}$ biosynthesis in polymorphonuclear leukocytes from blood of umbilical cord, infants, children, and adults. Pediatr Res 20:402-406

74. Strauss RG, Snyder EL 1984 Chemotactic peptide binding by intact neutrophils from human neonates. Pediatr Res 18:63-66

75. Hill HR, Augustine NH, Newton JA, Shigeoka AO, Morris E, Sacchi F 1987 Correction of a developmental defect in neutrophil activation and movement. Am J Pathol 128:307-314

76. Korchak HM, Vienne K, Ruthford LE, Wilkefield C, Filkelstein MC, Weissman G 1984 Stimulus response coupling in the human neutrophil: II. Temporal analysis of changes in cytosolic calcium and calcium afflux. J Biol Chem 259:4076-4082

77. Strauss RG, Nyder ELS 1985 Uptake of extracellular calcium by neonatal neutrophils. J Leukocyte Biol 37:423-429

78. Lagast H, Lew PD, Waldvogel FA 1984 Adenosine triphosphate-dependent calcium pump in the plasma membrane of guinea pig and human neutrophils. J Clin Invest 1984:107-115

79. Korchak HM, Weissman G 1978 Changes in membrane potential of human granulocytes antecede the metabolic responses to surface stimulation. Proc Natl Acad Sci USA 75:3818-3822

80. Seligmann BE, Gallin EK, Martin DL, Shain W, Gallin JI 1980 Interaction of chemotactic factors with human polymorphonuclear leukocytes: studies using a membrane potential sensitive cyanine dye. J Membr Biol 52:257272

81. Das M, Henderson T, Feig SA 1979 Neonatal mononuclear cell metabolism: further evidence for diminished monocyte function in the neonate. Pediatr Res 13:632-634

82. Miller ME 1975 Developmental maturation of human neutrophil motility and its relationship to membrane deformability. In: Bellanti JA, Dayton DH (eds) The Phagocytic Cell in Host Resistance. Raven Press, New York, pp 295-307

83. Miller ME 1979 Cell elastimetry in the study of normal and abnormal movement of human neutrophils. Clin Immunol Immunopathol 14:503510

84. Kimura GM, Miller ME, Leake RD, Raghunathan R, Cheung TW 1981 Reduced concanavalin A capping of neonatal polymorphonuclear leukocytes (PMNs). Pediatr Res 15:1271-1273

85. Strauss RG, Hart MJ 1981 Spontaneous and drug-induced concanavalin A capping of neutrophils from human infants and their mothers. Pediatr Res 15:1314-1318

86. Newton JA, Augustine NH, Hill HR 1987 Pentoxifylline enhances cell surface receptor mobility on the neutrophils of human neonates. Clin Res 35:217A

87. Newton JA, Augustine NH, Hill HR 1987 Pentoxifylline enhances cell surface receptor mobility on the neutrophils of human neonates. Pediatr Res 21:401A

88. Sacchi F, Augustine NH, Hill HR 1987 Abnormality in actin polymerization associated with defective chemotaxis in neutrophils from neonates. Int Arch Allergy Appl Immunol (in press)

89. Harris MC, Shalit M, Southwick 1987 Diminished F-actin content of neutrophils from term infants. Pediatr Res 21:408A

90. Hilmo A, Howard TH 1987 F-actin content of neonate and adult neutrophils. Blood 69:945-949

91. Roberts RL, Stiehm ER 1985 Uropod capping of concanavalin A (Con A) in cord blood and adult neutrophils. Clin Res 33:A387

92. Anderson DC, Freeman KB, Hughes BJ, Buffone GJ 1985 Secretory determinants of impaired adherence and motility of neonatal PMNs. Pediatr Res 19:257A

93. Jones DH, Schmalsteig FC, Rudloff HE, Burr BL, Smith CW, Smith CL, Prieto C, Dennison DK, Anderson DC 1987 Identification and quantitation of subcellular locations of Mac-1 (complement receptor -3) in neonatal neutrophils. Pediatr Res 21:409A

94. Anderson DC, Hughes BJ, Wible LJ, Perry GJ, Smith CW, Brinkley BR 1984 Impaired motility of neonatal PMN leukocytes: relationship to abnormalities of cell orientation and assembly of microtubules in chemotactic gradients. $\mathbf{J}$ Leukocyte Biol 36:1-15

95. Miller ME 1971 Chemotactic function in the human neonate: humoral and cellular aspects. Pediatr Res 5:487-492

96. Krause PJ, Herson VC, Boutin-Lebowitz J, Eisenfeld L, Block C, LoBello T, Maderazo EG 1986 Polymorphonuclear leukocyte adherence and chemotaxis in stressed and healthy neonates. Pediatr Res 20:296-300

97. Mease AD, Burgess DP, Thomas PJ 1981 Irreversible neutrophil aggregation: a mechanism of decreased newborn neutrophil chemotactic response. Am J Pathol 104:98-102

98. Mease AD, Fischer GW, Hunter KW, Ruymann FB 1980 Decreased phytohemagglutinin-induced aggregation and C5a-induced chemotaxis of human newborn neutrophils. Pediatr Res 14:142-146

99. McFall TL, Zimmerman GA, Augustine NH, Hill HR 1987 Effect of group $\mathrm{B}$ streptococcal type-specific antigen on PMN function and PMN-endothelial cell interaction. Pediatr Res 21:517-523

100. Pross SH, Hallock JA, Armstrong R, Fishel CW 1977 Complement and Fc receptors on cord blood and adult neutrophils. Pediatr Res 11:135-137

101. Marodi L, Leijh PCJ, van Furth R 1984 Characteristics and functional capacities of human cord blood granulocytes and monocytes. Pediatr Res 18:1127-1131

102. Miller ME 1969 Phagocytosis in the newborn infant: humoral and cellular factors. J Pediatr 74:255-259

103. Dossett JH, Williams RC Jr, Quie PG 1969 Studies on interaction of bacteria, serum factors and polymorphonuclear leukocytes in mothers and newborns. Pediatrics 44:49-57

104. Forman ML, Stiehm ER 1969 Impaired opsonic activity but normal phagocytosis in low-birth-weight infants. N Engl J Med 281:926-931

105. McCracken GH Jr, Eichenwald HF 1971 Leukocyte function and the development of opsonic and complement function in the neonate. Am J Dis Child 121:120-126

106. Strauss RG, Snyder EL 1983 Activation and activity of the superoxide generating system of neutrophils from human infants. Pediatr Res 17:662664

107. Strauss RG, Snyder EL 1983 Glutathione in neutrophils from human infants. Acta Haematol 69:9-14

108. Strauss RG, Snyder EL 1981 Neutrophils from human infants exhibit decreased viability. Pediatr Res 15:794-797

109. Ambruso DR, Altenburger KM, Johnston RB Jr 1979 Defective oxidative metabolism in newborn neutrophils: discrepancy between superoxide anion and hydroxyl radical generation. Pediatrics 64:722-725

110. Amruso DR, Bentwood B, Henson PM, Johnston RB Jr 1984 Oxidative metabolism of cord blood neutrophils: relationship to content and degranulation of cytoplasmic granules. Pediatr Res 18:1148-1153

111. Chirico G, Marconi M, Colombo A, Chiara A, Rondini G, Ugazio AG 1983 Deficiency of neutrophil phagocytosis in premature infants: effect of vitamin E supplementation. Acta Paediatr Scand 72:521-524

112. Muller R 1979 Pentoxifylline-a biomedical profile. J Med 10:307-429

113. Marcel GA 1979 Red cell deformability: physiological, clinical and pharmacological aspects. J Med 10:409-416

114. Schmalzer EA, Chien S 1984 Filterability of subpopulations of leukocytes: effect of pentoxifylline. Blood 64:542-546

115. Matrai A, Ernst E 1985 Pentoxifylline improves white cell rheology in claudicants. Clin Hemorheol 5:483-491

116. Buchanan N, Moodly GP 1979 The effect of pentoxifylline on human erythrocyte adenosine triphosphate. IRCS Med Sci 5:43-50 